\title{
IMPLEMENTASI MODEL “GEPPRAK” DALAM PEMBELAJARAN KEWIRAUSAHAAN UNTUK MENINGKATKAN MINAT BERWIRAUSAHA DI SEKOLAH MENENGAH KEJURUAN
}

\author{
Wiedy Murtini \\ Fakultas Keguruan dan Ilmu Pendidikan UNS \\ idik_53@yahoo.co.id
}

\begin{abstract}
Abstrak
Tujuan penelitian ini untuk mengeksplorasi pengalaman siswa SMK dalam mengimplementasikan model "GEPPRAK" dalam pembelajaran kewirausahaan. Fokus penelitian pada bagaimana siswa menginternalisasi nilai-nilai karakter, aspek soft skills dan transferable skills dalam pembelajaran Kewirausahaan sehingga siswa berminat untuk berwirausaha, Pendekatan penelitian adalah kualitatif fenomenologis. Orientasi penelitian untuk memahami, menggali, dan menafsirkan arti dari peristiwa-peristiwa, fenomena-fenomena dan hubungan dengan orang-orang secara alamiah dalam situasi tertentu, selama proses pembelajaran kewirausahaan. Data terkumpul melalui pengamatan, wawancara dan dokumentasi dideskripsikan apa adanya. Pendapat siswa, guru, perilaku, sikap, minat, keterampilan, kelemahan, merupakan bagian yang penting untuk memberikan masukan terhadap perbaikan pembelajaran kewirausahaan. Temuan menunjukkan bahwa antusiasme siswa tinggi, ditunjukkan dengan aktivitas dalam lima tahapan, project kewirausahaan dimulai dari (1) Grup (kelompok) kecil ,(2) Eksplorasi ,(3) Pengembangan ide usaha, (4) Penyusunan dan Presentasi rencana usaha, (5)Aksi dan Kompetisi usaha, berjalan dengan lancar dan berhasil meng internalisasi 3 nilai karakter dan 5 soft skills-transferable skills dengan skor tinggi sebanyak 68\% dan skor sedang 32\%. Semua produk terjual habis dan beberapa produk sudah menerima pesanan, hal ini menunjukkan indikasi tumbuhnya minat berwirausaha.
\end{abstract}

Kata kunci: kewirausahaan, nilai-nilai karakter, soft skills- transferable skills.

\section{“GEPPRAK" MODEL IMPLEMENTATION IN ENTREPRENEURIAL LEARNING TO INCREASE ENTREPRENEURSHIP INTENTION IN VOCATIONAL HIGH SCHOOLS}

\begin{abstract}
The purpose of this study to explore the experience of students SMK in implementing the model "GEPPRAK" in entrepreneurial learning. The focus of research on how students internalize the values of character, aspects of soft skills and transferable skills in entrepreneurship learning so that students interested in entrepreneurship, a qualitative research approach is phenomenological. Orientation research to understand, explore and interpret the meaning of events, phenomena and relationships with people naturally in certain situations, during the process of entrepreneurial learning. Data were collected through observation, interviews and documentation described what it is. Opinions of students, teachers, behavior, attitudes, interests, skills, weaknesses, an important part to provide input to the improvement of entrepreneurial learning. The findings indicate that students' enthusiasm is high, indicated by activity in five stages, starting an entrepreneurial project of (1) Groups (group) is small, (2)Exploration, (3) Development of business ideas, (4) preparation and presentation of business plans, (5) Actions and Competitions business runs smoothly and successfully upgrade internalization of three grades of character and five soft skills-transferable skills with high scores as much as $68 \%$ and the fair score was $32 \%$. All products sold out and some products are already taking orders, this indication of the growing interest in entrepreneurship.
\end{abstract}

Keywords: entrepreneurship, the values of character, soft skills - transferable skills. 



\section{PENDAHULUAN}

Penelitian ini bertujuan untuk mengeksplorasi pengalaman siswa Sekolah Menengah Kejuruan (SMK) dalam mengimplementasikan model Grup, Eksplorasi, Pengembangan ide, Penyusunan dan Presentasi, Aksi dan Kompetisi (GEPPRAK) dalam pembelajaran kewirausahaan. Fokus penelitian pada bagaimana siswa menginternalisasi nilai-nilai karakter, aspek soft skills dan transferable skills dalam pembelajaran kewirausahaan sehingga siswa berminat untuk berwirausaha. GEPPRAK adalah produk pengembangan model pengintegrasian nilai-nilai karakter dan aspek soft skills-transferable skills dalam pembelajaran kewirausahaan di SMK (Murtini, Sujadi, \& Noviani, 2013; Murtini, Sujadi, \& Noviani, 2014)

Program aksi pendidikan berbasis soft skills yang dilaksanakan Kementerian Pendidikan dan Kebudayaan (Kemendikbud) Indonesia sejak tahun 2005, dengan tema "SMK Pasti Bisa" kemudian diikuti dengan program "Pendidikan Karakter" dalam implementasinya menghadapi kendala-kendala. Pendidik yang sebelumnya hanya dituntut melatihkan soft skills, kini harus mengintegrasikan pendidikan karakter dalam proses pembelajaran.Sabandi, Sunarto, Kristiani, \& Murtini, (2011) menemukan bahwa pendidik masih mengalami kesulitan dan kebingungan dalam menentukan aspek-aspek apa saja yang perlu diinternalisasikan agar tidak terlalu membebani proses pembelajaran. Temuan lain dari penelitian tersebut adalah, dalam proses pembelajaran, aspek-aspek soft skills dan transferable skills penting dilatihkan pada para peserta didik di SMK.

Pengintegrasian soft skills, transferable skills dan nilai-nilai karakter dalam pembelajaran Kewirausahaan akan berdampak positif bagi penciptaan profesi wirausaha dan pengembangan jiwa wirausaha untuk kemajuan bangsa. Namun demikian, dalam pembelajaran Kewirausahaan cara-cara menentukan nilai-nilai karakter dan aspek soft skills maupun transferable skills apa yang perlu diinternalisasikan, belum ada standar baku, sehingga menyebabkan banyak guru mengalami kesulitan (Murtini et al., 2013). Permasalahan ini diperkuat oleh temuan (Colbeck, Campbell, \& Bjorklund (2000) menunjukkan bahwa caracara menginternalisasi nilai-nilai karakter ke dalam setiap mata pelajaran sampai saat ini belum ada prosedur. Murdiono (2010) menemukan bahwa dalam menginternalisasikan nilai-nilai moral religius setiap guru memiliki cara atau strategi yang berbeda-beda. Perbedaan disebabkan karena belum jelasnya nilai-nilai moral religius yang hendak ditanamkan dalam proses pembelajaran. Artinya, belum ada common values (nilai-nilai umum yang disepakati bersama) untuk diimplementasikan dalam proses pembelajaran di kelas.

Murtini et al. (2013), mengindentifikasi aspek-aspek soft skills dan transferable skills yang paling diperlukan dan penting untuk diinternalisasikan dalam pembelajaran kewirausahaan di SMK yaitu: administration skill, change skill, customer service skill, problem solving skills, counseling skills, sementara nilai-nilai karakternya adalah: berani, respect dan sportif. Selanjutnya Murtini et al. (2014) menemukan bahwa model pembelajaran kewirausahaan yang dapat menginternalisasikan soft skills, transferable skills dan nilai-nilai karakter tersebut adalah dengan melalui lima tahapan, dimulai dari tahap: (1) pembentukan kelompok kecil; (2) eksplorasi yang dilakukan di dalam maupun di luar kelas; (3) pengembangan ide usaha; (4) penyusunan dan presentasi rencana usaha; dan (5) pelaksanaan dan kompetisi usaha. Lima tahapan inilah kemudian diberi nama GEPPRAK agar lebih memudahkan untuk mengingat. " $G$ " adalah singkatan dari kata Grup atau kelompok. " E" adalah singkatan dari Eksplorasi, "P" Pengembangan Ide ," PR" singkatan dari Penyusunan dan Presentasi, " AK" singkatan dari Aksi dan Kompetisi. Dengan demikian GEPPRAK akan menjadi model baru yang akan dilaksanakan dalam pembelajaran kewirausahaan di SMKN 1 Ngawi untuk meningkatkan minat berwirausaha, dengan mengintegrasikan nilai-nilai karakter, soft skills dan transferable skills.

Nilai-nilai Karakter Davis (2003) mendefinisikan sifat karakter sebagai suatu watak yang bersifat tetap. Sekali terbentuk, karakter akan bertahan lama. Sementara itu, Hidayatullah, (2010) mendefinisikan karakter sebagai kualitas mental atau moral, akhlak atau budi pekerti seseorang yang merupakan kepribadian khusus yang menjadi penggerak seseorang melakukan sesuatu. Menurut Megawangi (2004), kualitas karakter meliputi sembilan pilar, yaitu: (1) cinta Tuhan dan 
segenap ciptaanNya, (2) tanggung jawab, disiplin dan mandiri, (3) jujur/amanah dan arif, (4) hormat dan santun, (5) dermawan, suka menolong, dan gotong-royong, (6) percaya diri, kreatif dan pekerja keras, (7) kepemimpinan dan adil, (8) baik dan rendah hati, (9) toleran, cinta damai dan kesatuan. Dengan demikian, orang yang memiliki karakter baik adalah orang yang memiliki kesembilan pilar karakter tersebut.

Siswandari \& Susilaningsih (2007) mendefinisikan transferable skills sebagai keterampilan yang dapat ditransfer di tempat kerja untuk menyelesaikan pekerjaan. Cara yang paling efektif untuk mentransfer skills adalah dengan mengikutsertakan siswa untuk melakukan tahapan pekerjaan dan mempraktikkan tahapan pekerjaan tersebut dalam konteks pelatihan lapangan dan melakukan pengulangan. Praktek merupakan kunci utama bagi seseorang untuk mengakuisisi skills yang baru. Jewish (2009) mengidentifikasi atribut penting transferable skills yang digunakan dalam dunia kerja, yaitu sebagai berikut: (1) komunikasi verbal, (2) komunikasi nonverbal, (3) menulis laporan, (4) bekerja dengan orang lain, (5) bekerja dengan teknologi dan informasi, (6) menganalisis masalah, (7) memecahkan masalah, dan (8) ber-organisasi.

Soft skills adalah seperangkat kemampuan yang mempengaruhi bagaimana manusia berinteraksi dengan orang lain. Definisi ini menunjukkan bahwa terdapat beberapa atribut soft skills yang merupakan atribut transferable skills (Jewish, 2009). Namun demikian menurut Pant \& Baroudi (2008) antara transferable skills dengan soft skill berbeda. Atributatribut transferable skills lebih banyak pada kemampuan teknikal, sementara atribut soft skill lebih pada kemampuan kepribadian dan interaksi sosial yang dikenal pada masyarakat kita. Soft skills dapat diklasifikasikan menjadi dua yaitu inter personal skills dan inra personal skills (Sunarto, 2015).

Manfaat Soft Skills-Transferable Skills bagi Lulusan sanga t diperlukan dalam perencanaan dan proses pencarian pekerjaan serta kesuksesan dalam meniti karir. Hal ini berarti soft skills menentukan pula seberapa cepat seorang lulusan akan mendapatkan pekerjaan. Gillard (2009) menyebutkan bahwa skills yang paling dicari oleh pemberi kerja adalah keterampilan komunikasi, integritas/kejujuran, keterampilan interpersonal, motivasi/inisiatif, etika kerja yang kuat, bekerja dalam tim, keterampilan komputer, analitis, fleksibilitas/ adaptibilitas, dan detail oriented. Beard, Clegg, \& Smith, 2007) menunjukkan bahwa sebanyak $87 \%$ orang kehilangan pekerjaannya atau gagal mengembangkan karier karena mempunyai gaya hidup dan perilaku yang tidak memadai, keterampilan kerja atau pengetahuan yang belum mencukupi. Perlunya kemampuan soft skills juga diperkuat oleh hasil survei yang dilakukan National Association of Colleges and Employers (NACE) tahun 2002 di Amerika Serikat. Soft skills sangat dibutuhkan lulusan SMK untuk dapat bersaing dalam mendapatkan pekerjaan, meniti karir dalam pekerjaannya dan untuk berwirausaha sendiri.

Dalam proses pembelajaran memasukkan unsur mengamati, menanya, mengumpulkan data, mengasosiasi dan mengkomunikasikan sesuai penerapannya pada fase-fase: (1) pembentukan kelompok kecil (small group building), (2) eksplorasi kewirausahaan (entrepreneur exploration), (3) pengembangan ide usaha (idea development), (4) penyusunan dan presentasi rencana usaha (preparing and presentation business plan), dan (5) pelaksanaan dan kompetisi usaha (action and business competitions).

\section{METODE PENELITIAN}

Qualitatif Fenomenologi research dipilih sebagai pendekatan penelitian ini. Orientasi penelitian fenomenologi, untuk memahami, menggali, dan menafsirkan makna dari peristiwa-peristiwa, fenomena-fenomena dan hubungan dengan para siswa secara alamiah dalam situasi pembelajaran kewirausahaan. Pengamatan terlibat (participant observation) terhadap fenomena sosial secara alamiah dan wawancara secara mendalam (dept interview) digunakan sebagai sumber data. Triangulasi sumber dan metode digunakan untuk menguji validitas data. Teknik analisis data menggunakan model analisis interaktif (Miles \& Huberman, 1984).

Purposive dan snow ball sampling digunakan dalam menyeleksi dan memilih subjek penelitian yang dilakukan di SMKN 1 Ngawi, Jawa Timur. Siswa dan guru Bidang studi Pemasaran yang mempelajari mata pelajaran Prakarya dan Kewirausahaan dipilih sebagai subjek penelitian (partisipan). Partisi- 
pan dalam penelitian ini terdiri dari dua guru mata pelajaran Prakarya dan Kewirausahaan di kelas 12, yang terdiri dari satu guru Bidang Studi dan satu guru bantu, serta para siswa yang berjumlah tiga puluh satu (31) siswa.

Teknik pengumpulan data dalam penelitian ini adalah teknik observasi, wawancara dan studi dokumenter. Observasi, peneliti melakukan pengamatan secara langsung dan mencatat kegiatan dalam proses pembelajaran kewirausahaan. Pengamatan dilakukan terhadap perilaku dan skills siswa didalam melaksanakan tugas-tugas kelompok, pengembangan ide usaha, observasi lapangan dan presentasi laporan tugas, persiapan dan penyusunan rencana usaha, aksi dan kompetisi usaha. Wawancara dilakukan terhadap guru dan siswa untuk menemukan permasalahan, kendala, dan pendapatnya terhadap pelaksanaan pembelajaran kewirausahaan. Metode dokumenter, mencakup dokumen tertulis berupa hasil penilaian kinerja kelompok dalam kegiatan obseravasi lapangan, presentasi ide usaha dan perencanaan usaha, serta aksi dan kompetisi usaha berdasarkan instrumen penilaian yang tersedia, serta gambar (foto), yang dapat memberikan informasi tentang pelaksanaan proses pembelajaran kewirausahaan. Triangulasi data, metode, dan peneliti dilakukan untuk menguji validitas dan reliabilitas data.

\section{HASIL PENELITIAN DAN PEMBAHASAN}

\section{Pembelajaran Kewirausahaan}

Dalam implementasi pembelajaran Prakarya dan Kewirausahaan di SMKN 1 Ngawi ini, siswa menerapkan Model "GEPPRAK" sebagai bentuk pengintegrasian nilai-nilai karakter, soft skills - transferable skills yang dituangkan dalam bentuk Model Pengintegrasian Nilai-nilai karakter, soft skill dan transferable skill dalam pembelajaran kewirausahaan seperti terlihat pada Gambar 1, berupa tahapan-tahapan (sintaks) proses pembelajaran yang terdiri dari lima tahapan pembelajaran. Proses pembelajaran untuk penanaman nilainilai karakter dilaksanakan melalui pembiasaan sikap berani, respek, sportif. Pembentukan soft skills dan transferable skills dilakukan melalui latihan-latihan administrative skill, counseling skill, change skill, problem solving skill, dan customer service skill. Komponenkomponen nilai-nilai karakter dan latihanlatihan tersebut merupakan significant content skills yang perlu dan mendesak dikuasai oleh siswa dalam membentuk karakter dan berjiwa wirausaha (Murtini et al., 2014). Kerangka Model "GEPPRAK" dalam pembelajaran kewirausahaan untuk mengintegrasikan nlai-nilai karakter dan soft skills-transferable skills dituangkan dalam Gambar 1.

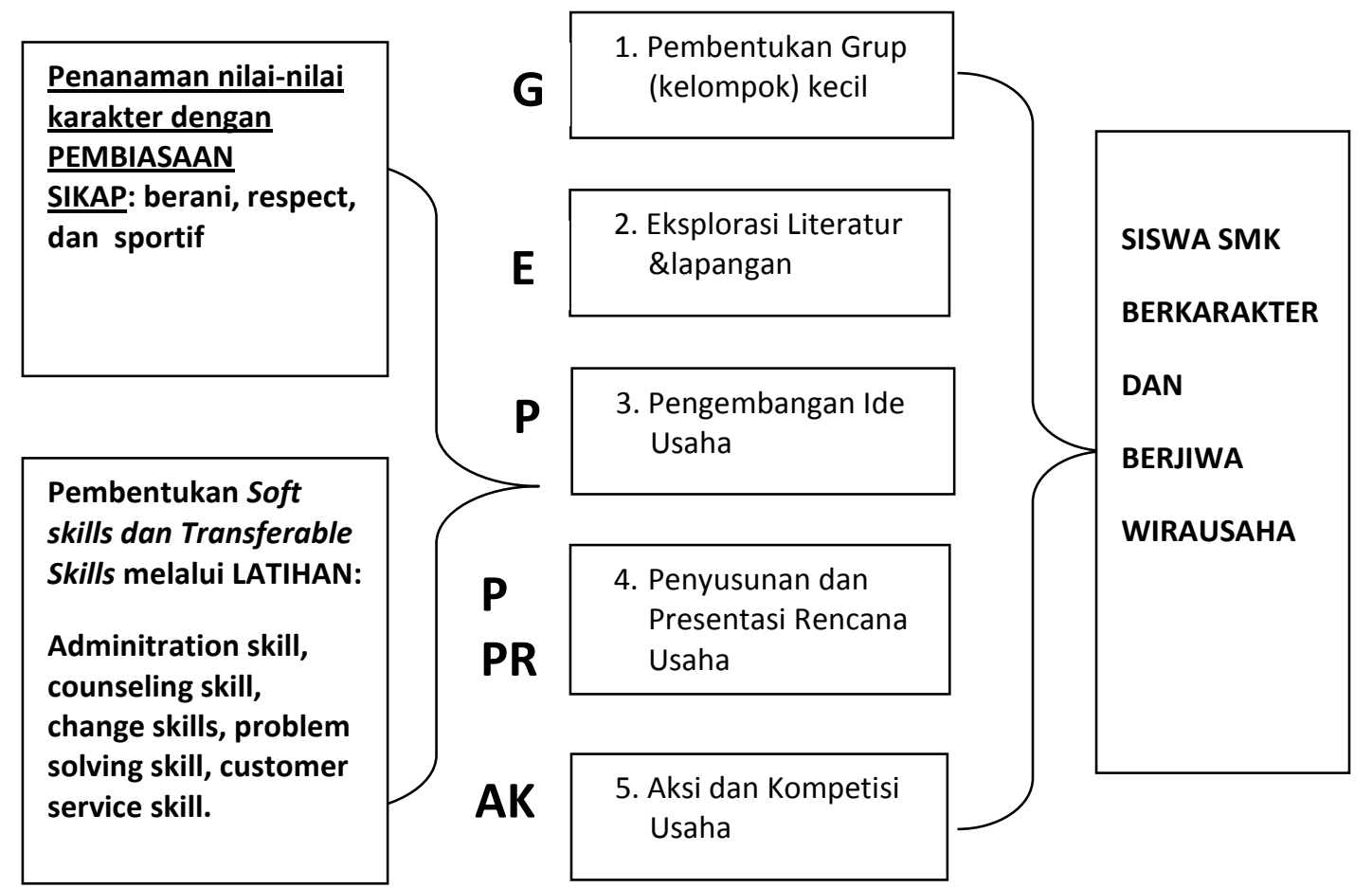

Gambar 1. Model Pengintegrasian Nilai-nilai Karakter, Soft Skill dan Transferable Skill dalam Pembelajaran Kewirausahaan. 


\section{Kerangka Operasional Model Pembelajaran}

Bentuk Kerangka Operasional Model Pembelajaran Pengintegrasian Nilai-nilai karakter, soft-skills dan transferable skills dalam pembelajaran kewirausahaan disajikan dalam Tabel 1.
Bidang usaha kerajinan yang dipilih SMKN I Ngawi berdasarkan pertimbangan kearifan lokal. Bidang usaha kerajinan yang dipilih ini sesuai dengan potensi daerah yang berada didekat hutan yang menghasilkan kayu jati dengan berbagai jenis varian produk mulai dari batang, ranting, pohon sampai akar yang ditinggalkan penebang pohon jati.

Tabel 1. Kerangka Operasional Model Pembelajaran GEPPRAK

\begin{tabular}{|c|c|c|c|}
\hline Kegiatan Guru & Langkah Pokok & Kegiatan siswa (sesuai RPP yg disiapkan) & $\begin{array}{l}\text { Jenis Keterampilan } \\
\text { dan perilaku } \\
\text { melalui pembiasaan } \\
\text { dan latihan }\end{array}$ \\
\hline $\begin{array}{l}\text { - Membentuk kelompok kecil } \\
4-5 \text { orang } \\
\text { - Kelompok heterogen } \\
\text { (kemampuan dan gender) }\end{array}$ & $\begin{array}{l}\text { 1. Membentuk } \\
\text { kelompok kecil }\end{array}$ & $\begin{array}{l}\text { - Membentuk kelompok dengan tertib } \\
\text { - Menjaga lingkungan belajar dan suasana yang } \\
\text { kondusif }\end{array}$ & $\begin{array}{l}\text { counseling skills } \\
\text { berani, respect, } \\
\text { problem solving, } \\
\text { sportif, change skills. }\end{array}$ \\
\hline $\begin{array}{l}\text { - Guru memunculkan masalah } \\
\text { yang berupa masalah/fakta di } \\
\text { lapangan. } \\
\text { - Menggali gagasan peserta } \\
\text { didik dalam menyelesaikan } \\
\text { masalah atau mencari ide-ide } \\
\text { kreatif. } \\
\text { - Guru membimbing siswa } \\
\text { dalam melakukan identifikasi } \\
\text { masalah. }\end{array}$ & $\begin{array}{l}\text { 2. Eksplorasi } \\
\text { literatur dan di } \\
\text { lapangan }\end{array}$ & $\begin{array}{l}\text { - Memperhatikan materi } \\
\text { - Mengkaji konsep dan contoh dengan bertanya } \\
\text { - Memahami permasalahan dan melakukan } \\
\text { identifikasi terhadap masalah yang dihadapi } \\
\text { - Siswa berpikir kritis untuk memecahkan } \\
\text { masalah. } \\
\text { - Mengamati dengan cara membaca dan } \\
\text { menyimak dari kajian literature/sumber } \\
\text { belajar lainny.a. Observasi lapangan ke } \\
\text { wirausahawan sukses tentang pengetahuan, } \\
\text { dan proses pelaksanaan usaha sesuai dengan } \\
\text { bidang usaha yang dipilih sekolah (mis: } \\
\text { kerajinan, pengolahan, budidaya, rekayasa) }\end{array}$ & $\begin{array}{l}\text { problem solving } \\
\text { skills, } \\
\text { counceling skils, } \\
\text { keberanian, } \\
\text { respek, sportif. } \\
\text { Administratif skill, } \\
\text { Change skills, } \\
\text { problem solving } \\
\text { skill. }\end{array}$ \\
\hline $\begin{array}{l}\text { - Guru membimbing siswa } \\
\text { untuk mengembangkan ide } \\
\text { usaha. } \\
\text { - Guru membimbing siswa } \\
\text { untuk melakukan analisis } \\
\text { SWOT terhadap ide usaha } \\
\text { yang akan dikembangkan. } \\
\end{array}$ & $\begin{array}{l}\text { 3.Pengembangan } \\
\text { Ide Usaha }\end{array}$ & $\begin{array}{l}\text { - Siswa menyusun laporan hasil observasi. } \\
\text { - Siswa mencatat dan mengidentifikasi ide- } \\
\text { ide usaha yang akan dikembangkan } \\
\text { - Siswa melakukan analisis SWOT terhadap ide } \\
\text { usaha yang akan dikembangkan. }\end{array}$ & $\begin{array}{l}\text { Administratif skills, } \\
\text { problem solving } \\
\text { skills, counseling } \\
\text { skills, sportif. }\end{array}$ \\
\hline $\begin{array}{l}\text { - Guru memberikan arahan } \\
\text { mengenai langkah-langkah } \\
\text { penyusunan rencana } \\
\text { bisnis/proposal usaha. } \\
\text { - Guru menciptakan suasana } \\
\text { kondusif dalam } \\
\text { pembelajaran. } \\
\text { - Guru menunjuk salah satu } \\
\text { wakil kelompok secara acak } \\
\text { untuk mengkomunikasikan } \\
\text { rencana bisnis . } \\
\text { - Guru memotivasi untuk } \\
\text { menjadi pemenang/yang } \\
\text { terbaik }\end{array}$ & $\begin{array}{l}\text { 4.Penyusunan dan } \\
\text { Presentasi } \\
\text { Rencana Usaha }\end{array}$ & $\begin{array}{l}\text { - Mengkoordinasi tugas } \\
\text { - Membagi tugas dengan anggota lain } \\
\text { - identifikasi masalah, } \\
\text { - mencari berbagai alternatif pemecahan } \\
\text { masalah } \\
\text { - menentukan alternatif pemecahan masalah } \\
\text { yang tepat } \\
\text { - Penyusunan rencana usaha secara } \\
\text { komprehensif } \\
\text { - Mempresentasikan rencana usaha } \\
\text { - Memberikan kritik dan saran serta penilaian } \\
\text { terhadap presentasi kelompok usaha lain. } \\
\text { - Evaluasi dan revisi }\end{array}$ & $\begin{array}{l}\text { administration skill, } \\
\text { change skill, } \\
\text { customer service } \\
\text { skills } \\
\text { problem solving } \\
\text { skills, counseling } \\
\text { skills } \\
\text { berani, respect dan } \\
\text { sportif }\end{array}$ \\
\hline $\begin{array}{l}\text { - Memantau kegiatan siswa } \\
\text { dalam melaksanakan rencana } \\
\text { bisnis } \\
\text { - Menilai hasil praktik usaha } \\
\text { - Menilai presentasi setiap } \\
\text { kelompok usaha } \\
\text { - Menentukan pemenang }\end{array}$ & $\begin{array}{l}\text { 5. Pelaksanaan } \\
\text { (action) dan } \\
\text { Kompetisi } \\
\text { Usaha }\end{array}$ & $\begin{array}{l}\text { - Mengkoordinasi langkah-langkah } \\
\text { pelaksanaan rencana bisnis } \\
\text { - Mempersiapkan marketing mix (produk, } \\
\text { tempat, harga, promosi) } \\
\text { - Menampilkan /menyajikan produk } \\
\text { - Menyusun laporan hasil usaha }\end{array}$ & $\begin{array}{l}\text { administration skill, } \\
\text { change skill, } \\
\text { customer service } \\
\text { skill, problem solving } \\
\text { skills, counseling } \\
\text { skills . berani, respect } \\
\text { dan sportif }\end{array}$ \\
\hline
\end{tabular}


Pembentukan karakter siswa di SMKN 1 Ngawi, dilaksanakan melalui pembiasaanpembiasaan yang dilakukan siswa dan ditanamkan melalui peraturan-peraturan sekolah. Hasil observasi lapangan terhadap situasi di sekolah menunjukkan karakter yang ditanamkan melalui kebiasaan-kebiasaan di sekolah, tampak jelas diterapkan dengan baik antara lain respek kepada orang lain yang ditunjukkan siswa dengan, senyum, sapa/ucapan salam, anggukan kepala, kepada semua tamu. Sebelum memulai dan sesudah pelajaran usai "selamat pagi, selamat siang, Assalamuallaikum (untuk siswa muslim) dan salam sejahtera bagi kita semua (-untuk siswa non-muslim)". Tidak lupa ucapan terima kasih disampaikan siswa kepada para guru setelah menyelesaikan pembelajarannya. Semua warga sekolah menerapkan kebiasaan senyum dan sapa ketika saling bertemu. Kebiasaan sportif ditanamkan dalam aturan sekolah dalam bentuk sebelum pelajaran dimulai, ketua kelas mengumpulkan semua handphone milik siswa di kelas untuk diserahkan ke guru piket yang berada di kantor sekolah dan akan diambilnya kembali ketika pelajaran sudah usai. Bagi peserta didik yang terlambat masuk kelas, mereka akan langsung menghadap guru piket untuk lapor dan memberikan alasan keterlambatannya. Setelah mengisi dan mendapatkan surat keterangan dari guru piket, siswa diperbolehkan untuk memasuki dan mengikuti pelajaran yang sedang berlangsung.

Keberanian ditanamkan kepada siswa pada kebiasaan untuk secara bergilir memimpin upacara sekolah, memimpin kelas, memimpin kelompok. Keberanian yang sudah ditanamkan oleh sekolah ini ditunjukkan oleh para siswa ketika melaksanakan pembelajaran praktik kewirausahaan dengan lima (5) tahapan proses pembelajaran, yaitu (1) Pembentukan Grup kecil, (2) Explorasi, (3) Pengembangan Ide Usaha, (4) Menyusun dan Presentasi Rencana Usaha, dan (5) Aksi dan Kompetisi Usaha. Tahapan pembelajaran kewirausahaan berlangsung sebagai berikut.

\section{Tahap Pembentukan Kelompok kecil (Small Group Building)}

Jumlah siswa kelas XII Bidang Keahlian Pemasaran SMKN I Ngawi berjumlah tiga puluh satu (31) dibagi menjadi enam kelompok. Pembentukan kelompok berdasarkan pada heterogenitas karakteristik kemampuan siswa yang selama ini sudah diterapkan oleh guru sekolah. Seperti yang dinyatakan guru kewirausahaan:" Saya sudah membagi siswa saya menjadi enam (6) kelompok sesuai dengan karakteristik kemampuan mereka, sehingga mereka bisa bekerja sama dengan baik". Kemampuan bekerja dalam tim nampak sekali dalam setiap kegiatan proses pembelajaran kewirausahaan. Hal ini didukung dengan pernyataan siswa partisipan; "kelompok kami kompak dan bekerja sama dengan baik bu.dalam setiap kegiatan“. Kerja sama yang menonjol dalam kegiatan diskusi kelompok membahas materi di kelas maupun di lapangan ketika melakukan observasi lapangan, mereka saling menghargai (respect) terhadap pendapat teman-teman kelompok, menghargai dan menghormati wirausahawan yang diwawancarai, membuat para siswa berani untuk mengemukakan pendapat. Hasil observasi menunjukkan diskusi siswa berlangsung ramai, saling adu argumen dan menyatakan pendapatnya masing-masing sebelum mereka menyepakati bersama ide mereka. Dengan demikian, kelompok-kelompok diskusi dan belajar yang sudah terbentuk sebelum studi eksplorasi menumbuhkan sikap kerja sama dan kekompakan tumbuh dengan baik.

Nilai-nilai karakter, soft skills dan transferabel skills yang ingin dibentuk dalam kegiatan kelompok ini adalah kemampuan untuk berdiskusi, berpendapat maupun meminta pendapat dan bertanya (driving question and need to know), menghargai pendapat orang lain, menghargai aturan main yang sudah ditetapkan guru, memecahkan permasalahan bersama dan menyepakati keputusan bersama yang telah dipilih dari berbagai alternative solusi (voice and choice), setelah dilakukan revisi dan refleksi (revision and reflection). Semua kegiatan dalam kelompok ini akan membentuk perilaku berani, respek, sportif dan administrative skills, counseling skills, problem solving skills, change skills. Ke-giatan kelompok berlangsung sampai dengan akhir pembelajaran.

\section{Tahap Eksplorasi (Exploration)}

Kegiatan Eksplorasi dimulai di dalam kelas dengan memperhatikan materi kewirausahaan, mengkaji konsep dan contoh dengan bertanya untuk memahami permasalahan dan melakukan identifikasi terhadap masalah yang 
dihadapi. Guru memberikan motivasi dengan memutarkan video tentang succes story para pengusaha. Siswa menyimak dengan baik dan mencermati hal-hal apa saja yang menarik dari kisah perjalanan sukses sang pengusaha dengan perjuangannya untuk meraih mimpinya. Fighting spirit yang dilakukan untuk mengatasi setiap kegagalan yang dialami, karakteristik dan kiat-kiat sukses adalah yang perlu diperhatikan, didiskusikan, dan disimpulkan oleh setiap kelompok siswa. Para siswa tampak senang diajak nonton video bersama, suasana kelas menjadi ramai senang ketika guru memberi tahu; " Anak-anak..kita sekarang akan menonton video bersama... tentang kisah sukses seorang pengusaha..Kita akan melihat kisah perjuangannya mulai dari sejak susah hidupnya sampai menjadi orang yang sukses!" .

Dengan mencermati setiap kisah perjuangan meraih sukses dari para pengusaha dan memberikan tugas untuk mengkritisi, guru melatih siswa untuk berpikir kritis, berani mengemukakan pendapat, memecahkan masalah dan mengambil keputusan. Sementara itu kelompok siswa juga diminta untuk berdiskusi dan menuangkan ide-ide usaha yang akan dirancang dan dikembangkan berikutnya. Dengan mencermati video kisah perjalanan sukses, siswa diharapkan terinspirasi dan juga termotivasi untuk berwirausha.

Tugas berikutnya guru meminta para siswa secara berkelompok melakukan observasi lapangan ke tempat wirausahawan sukses agar lebih mengenal dan mencari sumber belajar langsung kepada pelaku usaha di luar kelas. Siswa melakukan observasi, wawancara dengan para wirausahawan untuk mendapatkan pengetahuan, pengembangan ide usaha dan proses pelaksanaan usaha kerajinan (sesuai dengan bidang usaha yang ditentukan di sekolah) dan ide usaha yang akan dikembangkan.

Instrumen observasi berisi poin-poin tentang apa yang harus ditanyakan kepada wirausahawan sudah disiapkan guru. Beberapa siswa menyatakan bahwa:" Dengan adanya petunjuk penilaian observasi ini, kami mudah untuk menyiapkan pertanyaan apa saja yang ingin kami tanyakan kepada bapak pengusaha itu Bu..." Observasi lapangan dilakukan para peserta didik selain untuk membentuk karakter berani bertemu dan berkomunikasi dengan orang lain (public audience), juga untuk menghormati profesi wirusaha serta sportif untuk melaksanakan tugas yang sudah diberikan oleh gurunya. Seperti yang dinyatakan oleh seorang siswa; " awalnya saya tidak berani atau ragu apakah saya bisa menemui dan mewawancarai pengusaha itu bu.... takut...tapi karena kita berkelompok jadi.... berani saya untuk bertemu bapak itu! (maksudnya pengusaha). Siswa yang lain ada yang berkomentar;" Wah jadi pengusaha itu enak ya Bu...kaya..dan bisa menjadi Boss ". Tugas observasi lapangan diberikan untuk mendapatkan ide-ide kreatif dengan melakukan pengamatan, mewawancarai dan mengetahui bagaimana proses pembuatan, memasarkan, dan mengelola usaha.

Rekapitulasi skor observasi lapangan menunjukkan bahwa para peserta didik sudah melaksanakan kegiatan observasi lapangan dengan baik yang ditunjukkan dengan skor penilaian di atas 20 dari skor maksimum 30 . Tiga (3) kelompok mendapatkan skor 24, Satu (1) kelompok dengan skor 26 dan dua (2) kelompok dengan skor 27.

\section{Tahap Pengembangan Ide Usaha (Business Idea Development)}

Hasil observasi lapangan ke tempat wirausaha sukses dan diskusi kelompok, memunculkan ide usaha yang akan dikembangkan siswa. Kelompok pertama, "Woody Handmade"(kerajinan dari bahan limbah kayu dan bambu); kelompok ke dua, "Little Handmade" (kerajinan boneka mini dan bunga dari limbah plastik;, kelompok ke tiga "Avikalila Handycraft" (kerajinan rangkaian bunga dari bahan serbuk sabun); kelompok ke empat "Calika Accesories" (kerajian berbagai macam acsesories dari limbah plastik); kelompok ke lima "Brown Led"(kerajinan dari bahan limbah akar dan bonggol tanaman); dan kelompok ke enam "Djafa Lampions" (ke-rajian lampu hias dari limbah sendok plastik dan tutup botol bekas).

Pengembangan ide usaha merupakan kegiatan yang harus dilakukan oleh para peserta didik setelah melakukan kegiatan observasi lapangan ke tempat wirausaha sukses dibidang usaha yang ingin dikembangkannya. Diharapkan dengan kegiatan ini, para siswa telah memiliki ide usaha yang mantap akan dikembangkan ke depan dan mulai menyusun proposal usaha. Aspek penilaian yang dilakukan di sini antara lain para peserta 
didik melakukan analisis terhadap ide yang akan dikembangkan, yaitu mengenai (1) sumber ide darimana para peserta didik memperolehnya, (2) analisis kebutuhan pasar, (3) kreativitas ide, (4) kekuatan (strong), (5) kelemahan (weakness), (6) peluang (opportunity), dan (7) tantangan (threat). Rekapitulasi hasil penilaian tiap kelompok usaha di SMKN I Ngawi menunjukkan bahwa kelompok "Woody Handmade" memiliki skor yang paling tinggi dalam pengembangan ide usahanya. Kelompok ini membuat kerajinan dari bahan limbah kayu yang dibuat menjadi miniature rumah dilengkapi perabotan dan diberi lampu 5 watt yang bisa berfungsi sebagai lampu tidur. Pohon jati banyak tumbuh di daerah mereka, yang digunakan untuk berbagai macam bahan bangunan, perabot furniture, dan kerajinan lainnya. Sedangkan sisa limbahnya dimanfaatkan oleh siswa kelompok "woody handmade" untuk membuat kerajinan, selain miniature rumah, juga membuat hiasan tempat pensil, asbak, vas bunga dan lain-lain. Kreativitas dan kekompakan kerja sama mereka untuk menghasilkan ide pengembangan karya kerajinan yang dibutuhkan oleh masyarakat dengan memanfaatkan limbah yang tidak terpakai, seperti yang telah mereka ungkapkan dalam presentasi pengembangan ide usaha "kami memanfaatkan limbah kayu yang sudah tidak terpakai untuk membentuknya menjadi barang-barang yang menarik untuk menjadi hiasan yang fungsional". Hal ini menjadi point lebih dari penilaian terhadap mereka.

Kegiatan pengembangan ide usaha ini merupakan kegiatan yang penting untuk memulai membentuk usaha sebelum para peserta didik menyusun rencana usaha yang akan dilakukan. Ide-ide kreatif berkembang setelah hasil diskusi kelompok mendapatkan pencerahan, pengembangan dan pematangan dalam kegiatan observasi lapangan serta wawancara yang dilakukan terhadap para wirausahawan sukses. Temuan menunjukkan bahwa, proses amati, tiru dan modifikasi dengan sentuhan kreatif tidak bisa dihindari di sini. Seperti kerajinan membuat bunga plastik dengan pernak- perniknya, bunga yang terbuat dari serbuk sabun mandi dicampur bahanbahan pewarna dan perekat dengan kombinasi aksesories daun, batang dan pemilihan vas yang sesuai, dan kerajinan kayu bekas dan pelepah bunga tebu yang dibentuk miniatur rumah dengan isi perabotan sebagai aksesorisnya. Produk2 siswa ini kebanyakan memodifikasi karya-karya yang sudah ada, kemudian memberikan sentuhan kreatif. Temuan lain menunjukkan, bahwa potensi bahan yang melimpah dari lingkungan sekitar siswa yang tidak termanfaatkan, akan memunculkan kreativitas untuk membuat sesuatu yang bernilai guna.

\section{Tahap Penyusunan dan Presentasi Rencana Usaha (Prepare and Presentation Business Plan)}

Kegiatan Penyusunan dan Presentasi Rencana Usaha adalah kegiatan uji kelayakan dari ide usaha yang akan dilaksanakan dengan melalui proses bimbingan dan diskusi kemudian mempresentasikan rencana usahanya di depan kelas. Guru dan pengamat (peneliti) serta para siswa yang tergabung dalam kelompok-kelompok usaha saling mengkritisi dan memberi saran untuk penyempurnaan proposal usaha yang telah di susun. Temuan menunjukkan bahwa sebagian besar kelompok siswa tidak memasukkan komponen biaya (honorarium) pegawai atau tenaga kerja yang telah dikeluarkan untuk memproduksi usaha tersebut. Mereka kurang tahu untuk memperhitungkan tenaga kerja yang dikeluarkannya harus dimasukkan dalam biaya usaha. Beberapa siswa ada yang mengatakan; " $\mathrm{Bu}$, karena ini usaha baru maka kami tidak memperhitungkan honor untuk kami, nanti kalau sudah berkembang baru diperhitungkan". Ada yang menghitung harga produknya terlalu murah. Selain tidak menghitung honorarium pekerja, bahan baku produksi diambil dari rumah sendiri. Apalagi untuk bahan yang menggunakan limbah yang tidak membutuhkan biaya Contoh: akar pohon yang diambil dari halaman rumah, limbah kayu bekas, limbah plastik.

Presentasi rencana usaha berjalan dengan tertib dan lancar. Setiap kelompok meminta untuk mendapatkan kesempatan mempresentasikan rencana usahanya, walau rencana semula hanya akan dilakukan sampel random mengingat waktu yang tersedia. Mereka menggunakan kesempatan presentasi untuk mendapatkan masukkan dari rencana usaha yang dibuat. Semangat dan antusiasme para peserta didik menunjukkan kesadaran yang tinggi untuk mau menerima masukan dan kritikan serta keberaniannya untuk maju 
presentasi di depan kelas, menyampaikan pendapat dan menjawab pertanyaan dengan baik. Respek juga ditunjukkan dengan penghargaannya terhadap pendapat orang lain maupun teman-teman kelompoknya sehingga tercapai kesepakatan bersama dan penyempurnaan dari proposal usahanya.

Penyusunan dan presentasi proposal usaha merupakan sarana untuk melatih nilainilai karakter dan soft skills-transferable skills yang mereka miliki. Keberanian, respek, sportif dan administratif skills, counseling skills, problem solving skills, change skills, customer service skills yang dalam prosesnya nanti akan terakumulasi dalam kegiatan praktik usaha dan kompetisi usaha sehingga akan berhasil melaksanakan pembelajaran kewirausahaan dan berwirausaha.

\section{Tahap Aksi/praktik dan Kompetisi Usaha (Action and Competition).}

Kegiatan praktik dan Kompetisi Usaha merupakan tahapan akhir dari proses pengintegrasian nilai-nilai karakter, soft skills dan transferable skills dalam mata pelajaran prakarya dan kewirausahaan. Diharapkan dalam tahapan ini menunjukkan hasil yang positif sehingga akan menghasilkan lulusan SMK yang berkarakter dan berjiwa wirausaha.

Aspek-aspek yang dinilai dalam praktik dan kompetisi usaha ini adalah; kreativitas ide, volume penjualan, pemasaran (4P) price, product, promotion, dan place, manajemen keuangan, administrasi usaha, prospek pengembangan usaha, dan laporan hasil usaha. Hasil penilaian praktik dan kompetisi usaha menunjukkan kelompok "Avikalila Handycraft" mendapatkan skor tertinggi sebanyak 27, diikuti kelompok "Brown LED" 26, "Woody handmade" 25, "Djafa lampion" 24, "Little handmade" 23, dan terendah kelompok" Calika" dengan skor 22.

Kegiatan praktik usaha dan kompetisi usaha dilaksanakan di luar dan di dalam sekolah. Kegiatan praktik usaha di dalam sekolah sudah mulai terasa sehari sebelum kegiatan dengan kesibukan para siswa mempersiapkan tempat dan peralatan, serta barang-barang yang akan di display dalam stand-stand yang dibuat oleh mereka. Keceriaan tampak di wajah mereka, semangat untuk berkreasi dan berkompetisi ditampakkan dengan banyaknya kreasi-kreasi yang dihasilkan. Kegiatan penjualan produk juga di lakukan di luar sekolah dengan cara "door to door" ke kantor-kantor dan rumah-rumah disekitar sekolah. Kegiatan penjualan ke luar sekolah adalah untuk melatih mental, keberanian, dan mengasah keterampilan dalam melayani konsumen dari berbagai macam latar belakang sosial, pendidikan, ekonomi. Berdasarkan hasil pengamatan peneliti, semangat para siswa di dalam menjual, mempromosikan, dan melayani konsumen sangat membanggakan. Menurut pendapat para siswa, ini adalah pengalaman yang menarik dan menyenangkan. Mereka mengatakan "exited! walaupun capek, ini pengalaman baru kami yang menantang sekaligus menyenangkan bu!". Kegiatan dilakukan mulai pk.8.00 pagi sampai pk.14.00 baru kembali ke kelasnya masingmasing. Dari enam kelompok usaha, ada satu usaha "avikalila handycraft" yang memproduksi bunga dari bubuk sabun yang dicampur dengan bahan pewarna dan lem serta bahan pelengkap bunga seperti daun dan batang serta vas yang sesuai, sudah memperoleh pesanan dari konsumen pembeli. Para peserta didik diarahkan oleh guru untuk membuka web. site untuk melayani promosi dan pemesanan oleh konsumen.

Dalam kegiatan aksi dan kompetisi ini, setiap kelompok diberi bantuan masingmasing Rp. 200,000. sebagai modal usaha. Selain itu diberikan stimulan hadiah bagi para pemenang kompetisi usaha untuk Juara 1, 2, dan 3. Namun untuk memberikan motivasi kepada semua kelompok, guru memutuskan untuk membagi hadiah kepada semua kelompok sesuai dengan urutan juara 1,2,3,4,5, dan 6. Hal ini diterima dengan senang hati oleh para siswa.

\section{SIMPULAN DAN SARAN}

\section{Simpulan}

Hasil ekplorasi terhadap pengalaman siswa dalam implementasi model "GEPPRAK" dalam pembelajaran kewirausahaan menunjukkan bahwa pembiasaan atau habituasi karakter santun, berani, respek, sportif, tanggung jawab sudah ditanamkan dan dilaksanakan oleh pihak Sekolah (SMKN 1) melalui penerapan peraturan dan disiplin siswa dalam berperilaku dan kegiatan di sekolah. Penanaman nilai-nilai karakter dalam proses pembelajaran kewirausahaan sebaik- 
nya ditanamkan sejak dini. Untuk pembelajaran Kewirausahaan di SMK bisa dimulai sejak di kelas sepuluh (X). Penanaman nilainilai karakter sejak dini akan membentuk habit (kebiasaan) berperilaku.

Implementasi model "GEPPRAK", perilaku baik sebagai bentuk tertanamnya karakter berjiwa wirausaha, bersamaan dengan latihan-latihan soft skills - transferable skills terintegrasi dalam setiap tahapan pembelajaran kewirausahaan. Dengan tahapantahapan kegiatan yang sudah disiapkan dengan baik akan membantu siswa dan guru dalam mengintegrasikan nilai-nilai karakter, soft-skills-transferable skills sehingga dengan proses pembiasaan dan latihan akan terbangun karakter dan jiwa wirausaha. Untuk terus tumbuh dan berkembang, ini memerlukan proses dan waktu yang panjang dan berkelanjutan.

Pemilihan bidang usaha dalam mata pelajaran prakarya dan kewirausahaan yang ditentukan oleh sekolah yang disesuaikan dengan potensi daerah atau lingkungan sekolah (kearifan lokal) akan memberikan hasil yang lebih baik dalam usaha penanaman dan penumbuhkembangan jiwa wirausaha, serta memunculkan ide-ide kreatif untuk mengembangkan usaha.

Dalam menyusun rencana usaha, para siswa masih belum memperhatikan biaya yang harus dikeluarkan untuk honorarium kelompok kerja usaha mereka Seandainya ada, mereka memberikan jumlah nominal yang kecil atau kurang bisa menghargai tenaga sendiri.

\section{Implikasi}

Untuk menumbuhkembangkan jiwa dan minat berwirausaha para siswa, pihak sekolah perlu bekerja sama dengan Pemerintah Daerah dan para pengusaha untuk ikut membantu dan berkontribusi, baik dalam pelaksanaan proses pembelajaran maupun dalam mendukung permodalan, pengembangan usaha dan pemasaran.

\section{Saran}

Beberapa saran antara lain kepada pihak Sekolah, sebagai upaya mendukung dan mewujudkan program pemerintah dalam membangun karakter bangsa yang memiliki soft skills dan transferable skill, sekolah perlu menyediakan fasilitas dan sarana prasarana penunjang bagi guru-guru prakarya dan kewirausahaan dalam menerapkan pembelajaran praktik kewirausahaan.

Saran kepada para guru, pengintegrasian nilai-nilai karakter, soft skills, dan transferable skills dalam pembelajaran prakarya dan kewirausahaan perlu dilakukan agar para siswa lulusan SMK memiliki bekal karakter dan keterampilan yang sangat dibutuhkan di dalam memperoleh dan menciptakan lapangan pekerjaan. Guru di sini berperan sebagai fasilitator dan pelatih yang memfasilitasi dan melatih berbagai kegiatan kewirausahaan; diskusi kelompok, observasi lapangan, pengembangan/simulasi ide, menyusun rencana usaha dan praktik usaha.

Penelitian ini dapat digunakan sebagai acuan untuk mengembangkan penelitian sejenis, khususnya penelitian mengenai pendidikan kewirausahaan di SMK. Untuk peneliti lain dapat mengembangkan dengan mengubah atau menambah antecedent nilai-nilai karakter, soft skills, dan transferable skills berwirausaha, selain itu dapat juga dilakukan penelitian pada skala yang lebih luas.

\section{DAFTAR PUSTAKA}

Beard, C., Clegg, S., \& Smith, K. (2007). Acknowledging the affective in higher education. British Educational Research Journal, 33(2), 235-252. https://doi.org/10.1080/0141192070120 8415

Colbeck, C. L., Campbell, S. E., \& Bjorklund, S. A. (2000). Grouping in the Dark: What College Students Learn from Group Projects. The Journal of Higher Education, 71(1), 60-83. https://doi.org/10.2307/2649282

Davis, M. (2003). What's Wrong with Character Education? American Journal of Education, 110(1), 32-57. https://doi.org/10.1086/377672

Gillard, S. (2009). Soft skills and technical expertise of effective project managers. Issues in Informing Science and Information Technology, 6.

Hidayatullah, M. F. (2010). Pendidikan karakter: membangun peradaban bangsa. Surakarta: Yuma Pustaka. 
Jewish, C. (2009). Functional Transferable Tkills. Manitoba: Child and Family Service.

Megawangi, R. (2004). Pendidikan karakter: solusi tepat untuk membangun bangsa. Jakarta: Indonesia Herritage Foundation.

Miles, M. B., \& Huberman, A. M. (1984). Qualitative data analysis: A sourcebook of new methods. Thousand Oaks, CA: Sage.

Murdiono, M. (2010). Strategi internalisasi nilai-nilai moral religius dalam proses pembelajaran di perguruan tinggi. Cakrawala Pendidikan, 29(Edisi Khususn Dies Natalis UNY). Retrieved from

http://journal.uny.ac.id/index.php/cp/art icle/view/239/pdf_30

Murtini, W., Sujadi, I., \& Noviani, L. (2013). Model pengintegrasian nilai-nilai karakter, soft-skills dan transferable skill dalam pembelajaran kewirausahaan guna membangun karakter dan jiwa wirawusaha di SMK. Laporan Penelitian.

Murtini, W., Sujadi, I., \& Noviani, L. (2014). Model pengintegrasian nilai-nilai karakter, soft-skills dan transferable skill dalam pembelajaran kewirausahaan guna membangun karakter dan jiwa wirawusaha di SMK. Laporan Penelitian.

Pant, I., \& Baroudi, B. (2008). Project management education: The human skills imperative. International Journal of Project Management, 26(2), 124128.

https://doi.org/http://dx.doi.org/10.1016 /j.ijproman.2007.05.010

Sabandi, M., Sunarto, Kristiani, \& Murtini, W. (2011). Pengembangan effective team building untuk meningkatkan soft skill dan prestasi mahasiswa pendidikan ekonomi FKIP UNS pada perkuliahan matematika Ekonomi. Laporan Penelitian. Lembaga Penelitian dan Pengabdian Masyarakat UNS: Surakarta.

Siswandari, \& Susilaningsih. (2007). Pengembangan transferable skills mahasiswa melalui peningkatan kualitas pembelajaran statistika dalam rangka meningkatkan daya saing lulusan pendidikan tinggi. Laporan Penelitian Hibang Bersaing I. Surakarta: LPPM UNS.

Sunarto, M. J. D. (2015). Improvingstudents soft skills using thinking process profile based on personality types. International Journal of Evaluation and Research in Education (IJERE), 4(3, September), 118-129. 